\title{
The Need for a Reviewer to Play Devil's Advocate
}

\author{
Kun Hwang \\ Ethics Editor, Archives of Plastic Surgery
}

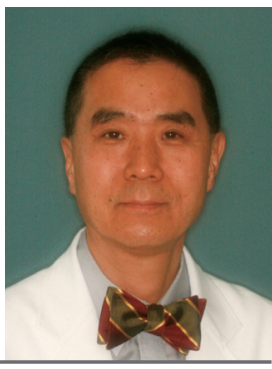

It has been over a year and a half since the Archives of Plastic Surgery (APS) was listed in PubMed Central. As an ethics editor, I have encountered cases of "salami slicing," "imalas," and duplicate publication, as well as plagiarism. However, I cannot be certain that there is no plagiarism in the issues already published because I have not reviewed all of them.

Although there are several sites that check the similarity of papers [1], these search engines cannot detect intelligently modified plagiarism' [2]. Thereafter the reviewer (referee) should read manuscripts in detail, look up the citations of the original paper, and identify missing papers that must also be cited.

The movie The Devil's Advocate (1997), in which Keanu Reeves and Al Pacino star as lawyers, comes to mind. The film's title is a reference to the commonly used phrase "devil's advocate." A devil's advocate is a person who expresses a contentious opinion in order to provoke debate or test the strength of the opposing arguments [3].

This terminology originated in the Roman Catholic Church tradition [4]: During the beatification or canonization process, the Church authorities appointed a lawyer to be the Promoter of the Faith (Latin: promotor fidei), popularly known as the Devil's advocate (Latin: advocatus diaboli), to argue against the canonization of a candidate based on the candidate's character or other evidence at hand (Another advocate was appointed to argue in favor of the candidate.) [5].

Likewise, in the APS review process, an editor sends a manuscript to 3 reviewers and they fill out several checklists, make comments to the author as well as to the editor, and each make a recommendation (accept as is, accept with minor revisions, major revisions, or rejection). In the case where two or more reviewers accept the manuscript, the editor usually accepts it for publication. In the case where two or more reviewers reject the manuscript, the editor usually rejects it.

I would like to propose that the editor choose at least one reviewer from the reviewer pool to play the role of "devil's referee." Like the devil's advocate in Catholicism examines how accurate the inquiry is, a devil's referee could examine the originality of the manuscript. He or she should take a skeptical view of the manuscript, looking for holes in the results of the experiment, insisting that the paper contain etwas neues (something new).

In the Catholic tradition, once a person becomes 'Blessed' or the 'Saint' through the beatification or canonization process, he or she is recognized for having an exceptional degree of holiness, sanctity, and virtue. Similarly, after publication, a manuscript becomes an 'article' and is cited in the research databases (PubMed, Scopus, etc.). In both cases, it is the consistent rigor of examination that lends value to the final status.

If unhappy cases of withdrawal after publication occur, the author is to blame. However, the editor and reviewers also hold some responsibility for preventing such cases in advance, to the best of their ability to detect irregularities. Creating a "devil's referee" role among the reviewers would strengthen the ethical publication standards of APS by ensuring that at least one person always evaluates each paper from a skeptical perspective.

\section{REFERENCES}

1. Kim JT. The value of originality and proper quotation. Arch Plast Surg 2012;39:279-80.

2. Huh S. How should authors address copyright issues before submission of manuscripts? Arch Plast Surg 2012;39:445-7.

3. Oxford dictionaries. Devil's advocate [Internet]. Oxford: 
Oxford University Press; c2013 [cited 2013 May 1]. Available from: http://oxforddictionaries.com/definition/english/devil\%27s\%2Badvocate?q=devil\%27s+advocate.

4. Wikipedia. Devil's advocate [Internet]. Wikimedia Foundation Inc.; [cited 2013 Apr 7]. Available from: http:// en.wikipedia.org/wiki/Devil\%27s_advocate.

5. Fanning W. Promotor fidei [Internet]. New York: Robert Appleton Company; 1911 [cited 2013 Apr 7]. Available from: http://www.newadvent.org/cathen/12454a.htm
Correspondence: Kun Hwang

Department of Plastic Surgery, Inha University School of Medicine, 27 Inhang-ro, Jung-gu, Incheon 400-711, Korea

Tel: +82-32-890-3514, Fax: +82-32-890-2918, E-mail: jokerhg@inha.ac.kr

No potential conflict of interest relevant to this article was reported.

Received: 10 Apr 2013 • Revised: 15 Apr 2013 • Accepted: 16 Apr 2013

pISSN: 2234-6163 • elSSN: 2234-6171

http://dx.doi.org/10.5999/aps.2013.40.3.171 • Arch Plast Surg 2013;40:171-172 